\title{
STUDY ON THE COMPOSITION OF MUNICIPAL SOLID WASTE IN KANCHIPURAM MUNICIPALITY
}

\author{
Pynthamil Selvi R. ${ }^{1}$, Joshua Amarnath ${ }^{2}$ \\ ${ }^{1}$ Consultant, Global Enviro Systems, Chennai \\ ${ }^{2}$ Professor \& Head, Department of Environmental Engineering, Sathyabama University, Chennai \\ E-Mail : ${ }^{1}$ pynthamilselvir@gmail.com
}

\begin{abstract}
Waste management has been a global environmental issue and has been a very significant problem in today's world. Municipal Solid Waste (MSW) generation in Kanchipuram has increased from 20 tonnes to 80 tonnes per day within the last 10 years. Due to urbanisation, change in lifestyle and food habits the amount of solid waste has rapidly increased accompanied by the change in composition of solid waste. Considerable amount of waste is being disposed without proper segregation leading to both economic \& environmental sufferings. The most common problems associated with improper management of solid waste include disease transmission, odour nuisance, atmospheric, land \& water pollution, fire hazards, aesthetical nuisance \& economic losses. A survey has been conducted among 215 households, where waste has been collected, segregated \& weighted by the help of Hand in Hand - a non government organisation. It has been done for a period of one month to understand the composition of MSW generated and to find out the per capita waste generation. It is better to segregate the waste at the household level where it is generated rather than segregating it centrally which is cumbersome \& expensive. The treatment and disposal has to be designed according to the different streams of waste generated rather than going for a single form of treatment. Appropriate planning and proper waste management has to be arrived and put in place after a thorough analysis of ground reality encompassing parameters such as social, economic, financial, legal, technical and environmental which would result in a holistic approach of solid waste management.
\end{abstract}

Keywords: Waste Management, MSWM, Segregation, Composition, Kanchipuram

\section{INTRODUCTION}

Municipal Solid Waste (MSW) includes commercial and residential wastes generated in municipal or notified areas, in either solid or semi-solid form excluding industrial hazardous wastes (MoEF, 2000). The quality and quantity of MSW generated by a particular community varies according to their socio-economic status, cultural habits, urban structure, population and commercial activities Government bodies at all levels-central, state and local bodies- and some non-governmental organisations (NGO) are taking proactive steps to tackle the issue of managing MSW. At present most of the MSW in the country is disposed off unscientifically (i.e.) lack of 'sanitary landfill'. This has adverse impacts on the ecosystem. Unscientific disposal practices leave waste unattended at the disposal sites, which attract birds, rodents, fleas etc., to the waste and create unhygienic conditions like odour, release of airborne pathogens, etc. The plastic content of the municipal waste is picked up by the rag pickers for recycling either at primary collection centres or at dumpsites. Plastic are recycled mostly in factories, which do not have adequate technologies to process them in a safe manner. This exposes the workers to toxic fumes and unhygienic conditions. Moreover, since the rag picking sector is unorganised, not all the recyclables, particularly plastic bags, get picked up and are found scattered everywhere, clog the drains and water bodies.

\section{AIM \& OBJECTIVE}

The aim of conducting this study is to,

- assess the public awareness on MSW.

- quantify of MSW generation

- determine the composition of MSW

- Identify problems related to MSWM

\section{A) About Kanchipuram:}

Kanchipuram municipality is located in the South West direction at a distance of $76 \mathrm{~km}$ from Chennai. It is situated at $12^{\circ} 50^{\prime}$ North Latitude and $79^{\circ} 42^{\prime}$ east longitude. The town has an average elevation of $83 \mathrm{~m}$ above Mean Sea Level (MSL). The main land lies on the northern bank of the River Vegavathi, a tributary of the River Pallar. The town has more than 1000 temples. It is also a fast growing town with many 


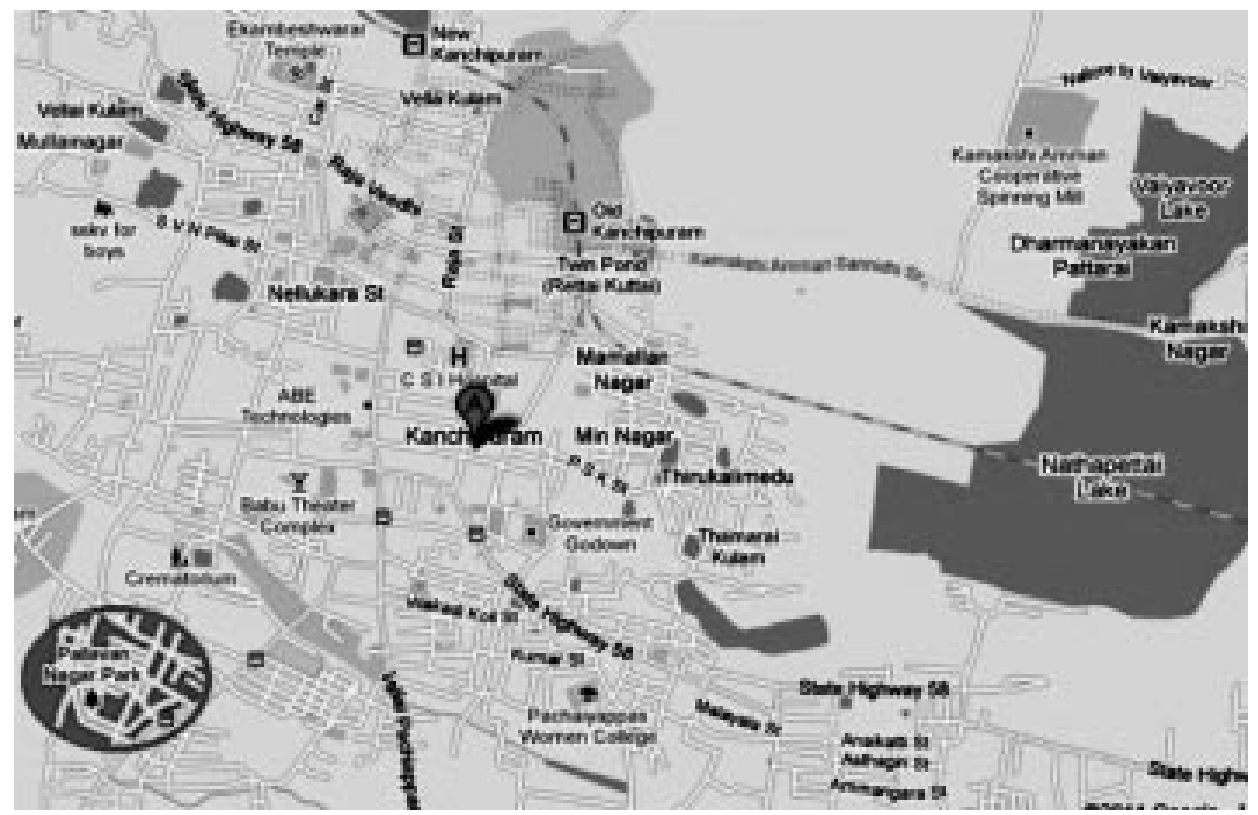

Fig 1. Tamilnadu map showing Kancheepuram location

Special Economic Zones around it. The town being a district head quarters and an important pilgrimage centre attracts daily floating population of about 18500 people. Total population of the city is around $1,66,300$ as per 2010 census of India report. The population of the city has increased nearly $10 \%$ within last 10 years. Due to urbanisation, change in lifestyle and food habits the amount of solid waste has rapidly increased accompanied by the change in composition of solid waste.

\section{B Study Area Pallavan Nagar is highlighted in Red Colour Circle in kanchipuram municipality map}

Pallavan nagar which is situated next to the Kanchipuram Collectorate has been selected for this study which comprises people from various socio economic background. The study area comprises of 215 houses with 816 people. Initially public awareness has been created among the people though personal interaction at household level, through questionnaires and by conducting interviews. This survey has been conducted by using Public Awareness Questionnaire. Hand in Hand, a NGO has been working on the MSW management in this locality for the last two years. With the help of 4 green friends from Hand in Hand, the waste generated from the houses has been segregated at a common point and has been weighed during the same duration. Upon analysis of the data the composition of MSW generated and the per capita waste generation have been arrived at.

\section{QUANTUM OF MUNICIPAL SOLID WASTE}

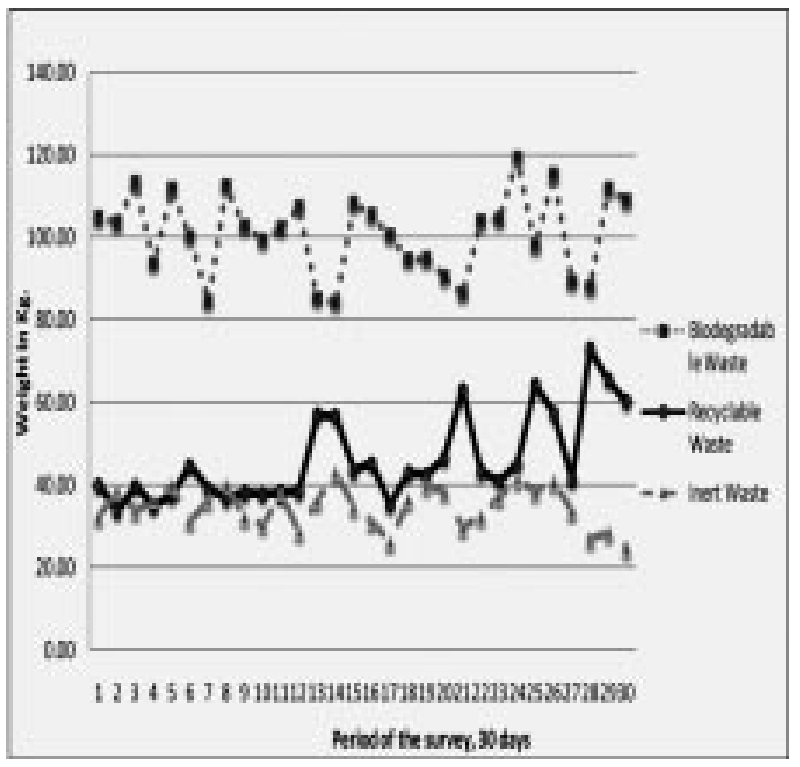

Fig.2: Quantum of MSW generated during the 30 day survey

Study Details:

Number of houses involved in the survey

\section{5 houses}

Total population in the Surveyed houses

\section{6 persons}

During the study period, 
Total solid waste generated in the area

$160-213.50 \mathrm{~kg} /$ day

Range of Biodegradable waste

$84.50-119.25 \mathrm{~kg} /$ day

Range of Recyclable waste

$33.75-73 \mathrm{~kg} /$ day

Range of Inert waste 24.75 - $43 \mathrm{~kg} /$ day

Average weight of Municipal Solid Waste generated $181.60 \mathrm{~kg} /$ day

Average per capita generation of MSW

\section{$0.22 \mathrm{~kg} /$ day}

As per CPCB norms, the per capita generation of solid waste in Class I cities ranges from $0.1 \mathrm{~kg} /$ day to $0.929 \mathrm{~kg} / \mathrm{day}$.

It was observed that weekly Monday \& Friday the amount of waste disposed is high, whereas weekends were comparatively less.

\section{COMPOSITION OF MUNICIPAL SOLID WASTE}

MSW mainly consists of household waste, construction \& demolition debris, sanitation residue and sweepings. The composition of MSW The composition of MSW has been listed below in Fig. 3

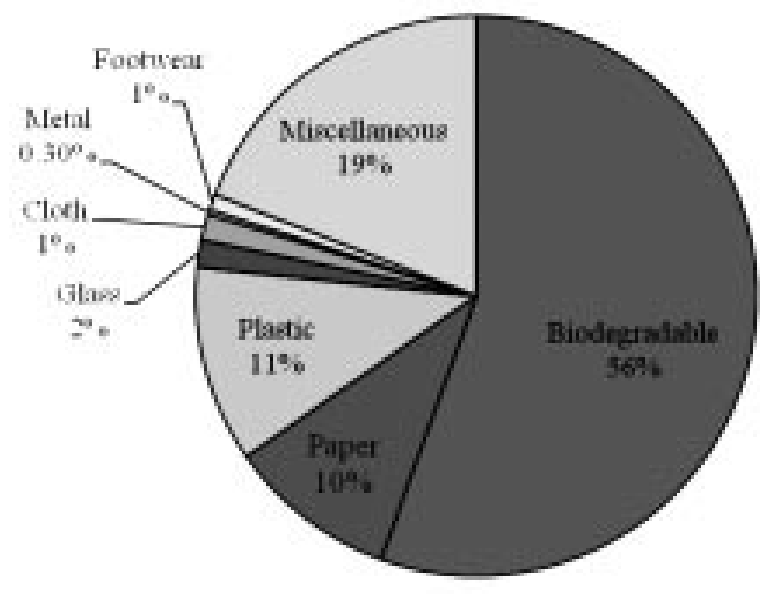

Fig. 3 Composition of municipal waste

The different types of waste materials found during the survey are tabulated below:
Table 1. Details of the Survey

\begin{tabular}{|l|l|}
\hline Type of Waste & \multicolumn{1}{|c|}{ Material Description } \\
\hline Biodegradable & Vegetable, Fruits, food, leaves, \\
\hline Paper & $\begin{array}{l}\text { Newspapers, magazines, } \\
\text { cardboard, package boards }\end{array}$ \\
\hline Plastic & $\begin{array}{l}\text { PET, PVC, HDPE, LDPE, PS \& } \\
\text { other plastic toys, medicine bottles }\end{array}$ \\
\hline Glass & Coloured glass, white glass, mirror \\
\hline Cloth & $\begin{array}{l}\text { Cotton, silk, rayon, fur, polyesters, } \\
\text { mixed }\end{array}$ \\
\hline Metal & $\begin{array}{l}\text { Steel, aluminium, copper, brass \& } \\
\text { nickel }\end{array}$ \\
\hline Footwear & $\begin{array}{l}\text { Leather, plastic, rubber, rexin \& } \\
\text { etc. }\end{array}$ \\
\hline Miscellaneous & $\begin{array}{l}\text { Sanitary waste, soiled cloth, } \\
\text { construction waste, lights. }\end{array}$ \\
\hline
\end{tabular}

From the study, it has been found that there has been a substantial increase in the amount of plastic in the MSW, which would result in environmental degradation upon not being managed properly.

Degradation time for each type of MSW generated has been given in Table. 2

Table 2 Degradation time of waste

\begin{tabular}{|l|l|}
\hline \multicolumn{1}{|c|}{ Type of Waste } & \multicolumn{1}{c|}{ Degradation Time } \\
\hline Biodegradable & $1-2$ weeks \\
\hline Paper & $10-30$ days \\
\hline Plastic & Upto 1000 years \\
\hline Glass & undetermined \\
\hline Cloth & Upto 1 year \\
\hline Metals & $100-500$ years \\
\hline Footwear & Undetermined \\
\hline Disposable Diapers & $400-500$ years \\
\hline Wood & $10-15$ years \\
\hline
\end{tabular}

Source: http://www.ecowarriors.it/index 


\section{CONCLUSION}

The public should be aware of the segregation at the generation point itself. They should be trained to store wet \& dry waste seperately. Collection should be done door to door to improve the efficiency. It should be segregated again thoroughly at a station and different categories of waste identified and sorted. Biodegradable waste can be compost by natural methods and by vermi composting. Energy recovery such as biogas, power generation could also be thought of as a measure using biodegradable wastes. The plastic bags and plastics can be transferred to the recycling stations. Newspapers can be transferred to the printing and pulp industry. Cloth can be recycled and can be used as wiping cloths and filling materials. Some types of glasses can be recycled. Other inert materials \& misellaneous resdues can be disposed in closed landfills.

Absence of historical data on composition of MSW and generation has limited the scope of the study. The variation in composition of MSW and the quantity at household over the years could have shed more light on the trajectory of MSW management in kanchipuram. Its recommeded that a proper ward level data base on compostion and generation has be maintained by the Kanceepuram Municipality so that management and investments could be made in a sustainable manner in the future.

\section{REFERENCES:}

1. George Tchobanoglous, H Theisen, S A Vigil, author of "Integrated Solid Waste Management - Engineering Principles \& Management Issues", published by McGraw Hill International Edition
2. Training Manual - "Developing Integrated Solid Waste Management Plan", prepared by United Nations Environmental Programme

3. CPHEEO (2000) "Manual on Municipal Solid Waste management" published by Central Public Health and Environmental Engineering, New Delhi, India

4. United Nations "Solid Waste Management in the world's cities - Water \& Sanitation in the world's cities 2010" published by UN Habitat.

5. Esakku. X, Swaminathan. A, Kurian. J, Prathiba Karthikeyan \& Palanivel, Municipal Waste Management in Chennai City, India proceeded in Saridina 2007 Eleventh International Waste Management \& landfill symposium, Italy

6. Sengtianthr V, Lao PDR., 2004.Solid waste Management in Urban Areas of Vientiane Capital City Using GIS. In: $30^{\text {th }}$ WEDC International Conference, Vientiane, August 2004.

7. Shaleen S \& Suneel P., 2001. Solid waste management in India: status and future directions. In: TERI Information Monitor on Environmental Science 2001.

8. Garg. R. K., 2002. National Solid Waste Association of India (NSWAI) Newsletter, Vol. 6, pp. 1.

9. Palnitkar. S, 2002. Manual of Solid Waste Management, AIILSG, Mumbai. pp. 9.

10. C. Visvanathan \& J. Trankler, Municipal Solid Waste Management in Asia: A comparitive analysis, http://www.swlf.ait.ac.th/data/Kasetsart\%20University\% 20National\%20Seminar\%20on\%20Solid\%20Waste $\% 2$ OLandfill\%20Ma/MSWM\%20in\%20Asia-final.pdf

11. http://www.nswai.com/waste-municipal-solid-waste.php

12. http://dste.puducherry.gov.in/envisnew/envislibrary.htm

13. http://www.cpcb.nic.in/oldwebsite/about\%20us/Division \%20at $\% 20$ Head\%20office/PAMS/Status\%20of\%20Mun icipal.html 